\title{
Moral exemplarism and atonement
}

\author{
Oliver D. Crisp ${ }^{*}$ \\ St Mary's College, University of St Andrews, Fife \\ ${ }^{*}$ Corresponding author. E-mail: odc@st-andrews.ac.uk
}

\begin{abstract}
In recent work on the doctrine of atonement there has been little positive said about the view that Christ's work is principally a moral example. This article addresses that lacuna. It sets out two versions of the moral example doctrine, which are often conflated in the literature. According to the first, Christ is merely a moral example. Such a view does not amount to a doctrine of atonement. According to the second, Christ's moral example brings about reconciliation with God through a transformative experience. This does amount to a doctrine of atonement. I raise some traditional objections to the moral example view and show that it has resources with which to withstand them. However, moral exemplarism still has difficulties dealing with a cluster of biblical motifs about atonement. In the final analysis, it is a partial but not complete account of the saving work of Christ.
\end{abstract}

Key words: moral example; Christ; atonement; reconciliation; transformative experience

Only the imitator is the true Christian.

\section{Søren Kierkegaard ${ }^{1}$}

In much historic Christian theology the atonement is the doctrine according to which Christ somehow reconciles fallen human beings to Godself by means of some saving act - usually focused in important respects upon his life and ministry, and culminating in his death on the cross and his resurrection. ${ }^{2}$ One important issue for those seeking to understand this Christian doctrine is what I shall call the mechanism of atonement. This is the means by which Christ brings about the reconciliation of fallen humanity with God. A central question for atonement theorists is this: how is it that Christ brings about the reconciliation of fallen humanity with God? What is the mechanism by means of which this obtains? That is the question that frames what follows. ${ }^{3}$

\footnotetext{
${ }^{1}$ Søren Kierkegaard, Practice in Christianity, vol. 20 of Kierkegaard's Writings, trans. Howard V. Hong and Edna H. Hong (Princeton: Princeton University Press, 1991 [1848]), p. 256.

${ }^{2}$ Not everyone sees it this way, however. For discussion of different ways of conceiving the nature of atonement, see Junius Johnson, Patristic and Medieval Atonement Theory: A Guide to Research (Lanham, MD: Rowman \& Littlefield, 2015).

${ }^{3}$ This is not uncontroversial among some biblical scholars. For instance, Michael Gorman is sceptical of attempts to provide what he calls 'the mechanics of atonement'. (We might dub this atonement mechanism (๑) Cambridge University Press 2020
} 
There are many different accounts of the atonement in the Christian tradition, with many different views on the mechanism of atonement. There are also accounts of Christ's work that do not amount to doctrines of atonement as such. This is often because the views in question deny that Christ's work and ministry are salvific. The theological importance of Christ's work for fallen human beings is thought to lie elsewhere. ${ }^{4}$ I will focus on a family of atonement views, at least some members of which do not amount to doctrines of the atonement in this sense, namely, moral exemplarist views. Put very roughly, moral exemplarism is the view according to which Christ's work is primarily an example that should elicit a particular transformative response in individuals that encounter it, rather like a single act of courage in the midst of a pitched battle may have the effect of transforming terrified members of an army corps into a fighting unit, thereby turning the tide of the conflict. It is often said that moral exemplarist views are somehow theologically deficient, though where the deficiency lies is rather more difficult to say. ${ }^{5}$ However, there are far fewer attempts to defend moral exemplarism, let alone argue that at least some versions of moral exemplarism do, in fact, constitute atonement doctrines.

This article does just that. I will outline two distinct strands of moral exemplarism. The first, which I shall call mere exemplarism, does not yield a doctrine of atonement, though it does provide a way of thinking about Christ's life and ministry that is theologically salient. According to mere exemplarism, Christ's work is merely an example that should elicit a particular response in individuals that encounter it. Although a moral example can be a powerful thing - think of some modern examples like St Teresa of Calcutta, or Martin Luther King, Jr., or Dietrich Bonhoeffer - someone who is merely a moral example is not a person whose work is salvific in the sense of bringing about reconciliation of the individual with God. Mere moral examples may bring about profound transformation of one's relationships with other human beings, but they do not necessarily have any Godward reference, and so do not (and, lacking such reference, by definition cannot) bring about reconciliation with God. So their role as moral exemplars is not salvific.

I will contrast this mere exemplarism view with a richer account, which I shall call extended exemplarism. This extended account includes almost all that the mere exemplarist view entails, aside from the restriction that the exemplarism in question is a 'mere' exemplarism. It goes beyond mere exemplarism to suggest a way in which

scepticism - a matter to which I shall return at the end of the article.) He writes, 'New Testament writers are far less interested in the mechanics of atonement than they are in the results of atonement. In fact, I would suggest that the mechanics are largely a mystery and will always be precisely that' (Michael Gorman, The Death of the Messiah and the Birth of the New Covenant (Eugene, OR: Wipf \& Stock, 2014), p. 210). But, pace Gorman et al., many historic Christian theologians working on this topic have been interested in the 'mechanics of atonement' as much as the results of the atonement, as any standard textbook on the subject would quickly demonstrate.

${ }^{4}$ However, some accounts of the work of Christ do not amount to a doctrine of atonement because they do not provide a clear view of the mechanism of atonement rather than because they deny the work of Christ is salvific. I think that some versions of the ransom view are like this. For discussion, see Oliver D. Crisp, 'Is Ransom Enough?', Journal of Analytic Theology 3 (2015), pp. 1-11.

${ }^{5}$ See e.g. Alister E. McGrath, 'The Moral Theory of the Atonement: An Historical and Theological Critique', Scottish Journal of Theology 38 (1985), pp. 205-20. The idea that imitating Christ's example is integral to the Christian life - and especially for Christian sanctification - is, however, much less controversial. For an intriguing recent treatment of this issue, see Joshua Cockayne, 'The Imitation Game: Becoming Imitators of Christ', Religious Studies 53 (2017), pp. 3-24. 
Christ's work is, in fact, atoning. So, on this richer account Christ's action, in addition to being a moral example that should elicit a particular response in individuals that encounter it, is also salvific: it brings about reconciliation with God. Having outlined the two versions of exemplarism, I will defend them against several standard objections. Although I do not endorse a version of exemplarism as a stand-alone account of Christ's work, like almost all atonement theorists, I think that this way of conceiving Christ's work represents an important feature of any adequate understanding of the atonement, even if it needs to be augmented in important respects in order to yield an acceptable account of the atonement. In this way, we might characterise at least some version of exemplarism as a necessary but not sufficient feature of a complete account of the atonement. But if that is right, then it is worth trying to get a clearer picture of the conceptual shape of different versions of moral exemplarism as contributing factors to a doctrine of atonement. It is also worthwhile asking why moral exemplarism may not be sufficient as a way of conceiving Christ's saving work.

We shall proceed as follows. In the first section I give some distinctions that set up the discussion. Then in the second section I outline the mere exemplarist view and distinguish it from the extended exemplarist view. The third second section raises some problems for moral exemplarist approaches to the work of Christ. Finally, the conclusion draws together the strands of the foregoing, offering some reflections on how this discussion fits into a broader atonement theology.

\section{Some introductory remarks}

Before setting out the two versions of moral exemplarism, some introductory remarks are in order.

First of all, I shall refer to all the features of Jesus of Nazareth's career, including his ministry, teaching, death and resurrection, as the work of Christ. This elides the question of what it is about Christ's life and ministry including his death and resurrection, that is salvific - a matter that is contested in the Christian tradition. For some theologians (Anselm and Calvin, amongst others) Christ's incarnation, life and ministry are a kind of prerequisite for his crucifixion, which is what is salvific. For others (including Athanasius and Irenaeus), however, his incarnation and ministry are just as much a part of his reconciling work. We do not need to take a view on this matter here. In any case, the exemplarist tradition tends to treat both Christ's life and ministry, as well as his death and resurrection, as in some sense works (or aspects of one work) that are exemplary. This is true even though the cross is usually the focus of discussion, as with most other historic accounts of the work of Christ. Note that I do not say that for the exemplarist these different aspects of Christ's life, work and ministry are salvific either individually or taken together. For (as we shall see) that is one of the central matters at issue in the exemplarist tradition.

Next, I shall not spend much time discussing theologians that represent the exemplarist tradition. There is some dispute about whether particular thinkers should be included in this way of thinking about the work of Christ, perhaps the most famous of whom is the medieval Parisian theologian, Peter Abelard. ${ }^{6}$ But for our purposes, it

\footnotetext{
${ }^{6}$ For an essay that denies Abelard was a mere exemplarist, see Philip L. Quinn, 'Abelard on the Atonement: "Nothing Unintelligible, Arbitrary, Illogical, or Immoral about It", in Oliver D. Crisp (ed.), A Reader in Contemporary Philosophical Theology (London: T\&T Clark, 2009), pp. 335-53. Also worthy
} 
is sufficient that (a) this way of thinking about the work of Christ has a long history, and (b) there are clear and undisputed representatives of this way of approaching Christ's work in the Christian tradition. ${ }^{7}$ These two things are not at issue in the atonement literature.

\section{Two versions of moral exemplarism}

In a recent reference work on the topic, Adam Kotsko writes, 'Exemplarism, sometimes also called the "moral influence theory" of the atonement, refers to the view that the primary goal of Christ's saving work is to produce positive moral change in human individuals and communities. ${ }^{8}$ This is a fairly common characterisation of the view. The idea is that moral exemplarists make positive moral change the primary goal of the atonement, and that this privileging of moral change over other potential outcomes distinguishes it from alternative accounts. The problem is that this leaves unexplained how the moral exemplarist view amounts to an account of Christ's work as an atonement; that is, how this conception of the work of Christ is supposed to be salvific, as opposed to a non-salvific account of Christ's work. For on the face of it, the claim that the exemplarist regards Christ's atonement as primarily a matter of producing moral change in human persons seems ambiguous. It is not clear whether what is in view is a claim about moral change/transformation, or, alternatively, a claim about salvation. ${ }^{9}$

Kotsko seems to think that matters may be clarified by appealing to the oft-repeated theological distinction between so-called 'subjective' and 'objective' accounts of the atonement. According to 'subjective' views, the importance of Christ's reconciling work has to do with its appropriation by a particular individual, and the subjective change the person undergoes as a consequence. By contrast, 'objective' views of the atonement are those according to which the most salient feature of Christ's reconciling work is his action on behalf of the believer in salvation, independent of the change this brings about in the particular individual believer. But since all accounts of the atonement include both 'subjective' and 'objective' elements in the sense these terms are being used here, this is not very illuminating. If moral exemplarism does in fact provide us with a doctrine of the atonement, then what is the mechanism of atonement? How is Christ's moral example or moral influence supposed to be salvific? This is never explained.

It is precisely this explanatory lacuna that I want to address. As far as I am aware, there is no other treatment of exemplarism that distinguishes something like mere exemplarism from something like extended exemplarism. When the exemplarist

of mention in this connection is Thomas Williams, 'Sin, Grace, and Redemption', in Jeffrey E. Brower and Kevin Guilfoy (eds), The Cambridge Companion to Abelard (Cambridge: Cambridge University Press, 2004), pp. 258-78. The locus classicus is now translated as Peter Abelard, Commentary on the Epistle to the Romans, trans. Stephen R. Cartwright (Washington, DC: Catholic University of America Press, 2011), the editorial introduction to which sets out the issues relating to the interpretation of Abelard's position on the atonement.

${ }^{7}$ Paradigmatic exemplarists include the Italian-Polish Reformation-era theologian, Faustus Socinus; Immanuel Kant; the 'father of modern theology', Friedrich Schleiermacher; the twentieth-century Anglican philosopher and theologian, Hastings Rashdall; and, in more recent times, John Hick.

${ }^{8}$ Adam Kotsko, 'Exemplarism', in Adam J. Johnson (ed.), T\&T Clark Companion to the Atonement (London: Bloomsbury T\&T Clark, 2017), p. 485.

${ }^{9}$ We shall see that in the case of extended exemplarism, it is both. But these two things (namely, moral change and salvation) are not synonymous. 
tradition is discussed, it is usually as a form of what I am calling mere exemplarism (what Kotsko, following the older atonement literature, calls 'moral influence theory'). This is a pity. As we shall see, there is an important distinction to be made here - one that has potentially significant implications for our understanding of the doctrine of atonement.

\section{Mere exemplarism}

According to mere exemplarism, Christ's work is a moral example to us of how we ought to live - a life of self-sacrificial love culminating in the giving up of his own life in order to vindicate his message. But it is not in addition to this a means by which we are reconciled to God. Comparisons with other great moral teachers would yield a similar picture. Thus, if we were to consider the moral example of Dr Martin Luther King, Jr., St Teresa of Calcutta, or even of philosophers like Socrates, or other religious figures like Gautama Buddha, much the same could be said of them as is said of Christ in mere exemplarism. They are moral examples. Their lives provide a pattern of moral living, perhaps even a kind of loose framework to which one might want to conform. (This may be easier in some cases rather than others. For instance, I am not sure all the recorded aspects of Socrates' life are exemplary or provide a clear moral framework that might be imitated. However, the legends of Gautama Buddha's life are for some people exemplary, and his teaching on the Four Noble Truths and the Eightfold Path have provided the basis for the various traditions of Buddhism.)

Saying that Christ's work may be a mere moral example does not trivialise or disparage the significance of his work for those who take this view. (The qualification 'mere' in mere exemplarism should be read like the 'mere' of Lewis's Mere Christianity, not the 'mere' of a mere trifle.) It is perfectly consistent with mere exemplarism that the sort of change this brings about in the person who takes to heart the moral task of conforming her life to that of Christ is in fact transformative in the way in which Laurie Paul speaks of transformative experience. ${ }^{10}$ Such experiences can certainly be momentous and lasting. To see this, consider the following example:

Smith is a professor of ethics with no clear religious affiliation. In her search for the good life, she reads the works of many different moral thinkers, and eventually alights upon the teaching of Christ as reported in the Sermon on the Mount in Matthew 5-7. Intrigued, she begins to read all four of the canonical Gospels, beginning with Matthew, and progressing through Mark to Luke and John. She finds herself deeply moved by the person of Christ as he appears in these narratives. His moral teaching on simplicity of life, and self-sacrificial love, and devotion to God and to the community, and especially to the poor and disadvantaged, is something that resonates deeply with her desire to find a comprehensive moral vision that may shape her own interior life. Upon reading about Christ's passion, she is struck by how he is portrayed as living out a consistent ethic, even though it ultimately costs him everything, rather like Socrates. Yet here, in Christ, is an

\footnotetext{
${ }^{10}$ L. A. Paul, Transformative Experience (Oxford: OUP, 2014). In this connection, Joshua Cockayne writes, 'Copying certain examples of behaviour from historical individuals might change our own thinking and behaviour in certain ways. However, if imitating Christ is essential for the redemption of human agents through the process of sanctification, and eventually, deification, then it will be important that our account of imitation captures the transformative nature of this process. It is not obvious that mere behaviour replication can do this' (Cockayne, 'The Imitations Game', p. 7). That seems right to me.
} 
example of someone who sought not merely to teach the youth to be critical of authority, or to question everything, but who sought to provide a deep and consistent moral foundation upon which a person may grow and flourish. Nowhere is this more evident than in the manner in which Christ forgives his executioners from the cross upon which he was crucified.

The effect upon Smith is profound. She reads and rereads the Gospels, Mark being her favourite because of its immediacy. The person of Christ jumps out of the page, arresting her with each new reading. Through this engagement with the text of scripture, and deep reflection upon what she has been reading, Smith comes to see that Christ's work, teaching and, ultimately, his self-sacrifice on the cross for the principles that guided his life, presents an irresistible picture. He is a model of the good life, an exemplar like no other she has encountered in her research. For in the person of Christ, there is a combination of piety, devotion to duty, purpose, clear moral teaching of the highest order and a ministry suffused with a desire to love others, and address their physical and spiritual needs, especially with respect to the poor and marginalised. Transfixed by the moral example of Christ and his self-sacrificial act of crucifixion, Smith undergoes a significant moral and spiritual reorientation. She vows to amend her life in order that she may align herself and her religious convictions with the example of Christ as a model for the good life that is predicated upon the need to love other people in her community, and especially the poor and disadvantaged, in practical ways in order to bring about moral and political change.

In her work on transformative experiences, Laurie Paul distinguishes between epistemic transformation and personal transformation. An experience is epistemically transformative if you can only know what it is like by undergoing the transformation yourself. For instance, seeing a particular colour for the first time. A personal transformation is one in which your view on an issue that is fundamental to who you are is changed. For example, reading The Communist Manifesto and having one's political views changed forever as a consequence. When a transformative experience includes both an epistemic and personal aspect it is truly transformative. A good example of this is becoming a parent. Those who have become parents often say that it is a transformative experience that they could not have prepared themselves for, and did not fully understand, prior to actually having a child. Something about undergoing the experience of becoming a parent for oneself changes a person, in a way that no textbook could explain adequately.

Religious conversion is another paradigm of truly transformative experience, because it, too, has both epistemic and personal aspects. In the example of Smith, we have an instance of an experience that is arguably transformative. It may even be a kind of religiously transformative experience - that is, truly transformative, including epistemic and personal aspects. There are certainly secular followers of Christ whose encounters with his life and teaching could be characterised in terms of non-theistic religious experiences that are transformative in this sense. ${ }^{11}$ I say 'non-theistic religious experience that is transformative' advisedly. For it seems to me that one could have a religious experience that is transformative on the basis of an encounter with the Christian

\footnotetext{
${ }^{11}$ One recent popular example, born out of work being done in conversation with Miroslav Volf at Yale's Center for Faith and Culture, is Tom Krattenmaker, Confessions of a Secular Jesus Follower: Finding Answers in Jesus for Those Who Don't Believe (New York: Convergent Books, 2016).
} 
understanding of the work of Christ as found in the canonical Gospels, and yet not become a theist as a consequence, let alone a Christian. ${ }^{12}$ Alternatively, it seems feasible for a person to encounter the biblical portrayal of Christ and undergo a theistic religious transformative experience (either from a prior state of atheism or agnosticism, or just plain old religious apathy) yet without becoming a Christian as a consequence.

Such transformative religious experiences do not yield the sort of moral and spiritual reorientation that includes reconciliation with Godself, as one would expect if the transformation were salvific - that is, part of an account of Christ's work understood in terms of atonement. For, as we have characterised Smith, her engagement with the work of Christ lacks certain markers that one would expect for the exemplarism in question to be recognisably salvific in nature. There is no indication that she has an awareness of sin, or an understanding of the need for Christ to reconcile her to God, for example. In fact, there is no reason to think that Smith's engagement with Christ's work as an instance of mere exemplarism has anything about it that marks it out as distinctively Christian. Smith could do all she is reported as doing in the story and it change her in significant ways yet without her becoming a member of a believing community, holding to any distinctively Christian doctrines, or engaging in any particular Christian practices. Even if we have a very minimal account of what change an agent must undergo in order to become a Christian or a member of a Christian faith community, ${ }^{13}$ it looks like Smith's experience could be significant and transformative in some important, perhaps even significant respects, without her becoming a Christian.

Now, Christ's work may be atoning even if Smith is not aware that it is atoning. I am not denying that. In other words, she may be saved by the atonement without knowing it, and whilst committed to a mistaken account of the work of Christ. There is nothing particularly implausible in that suggestion. But then, Christ's work would be an atonement for sin, and mere exemplarism would therefore be false. Given that Smith holds views consistent with mere exemplarism even after her transformative engagement with the work of Christ, she would (on this way of thinking) remain committed to a false picture of Christ's work. God may still include her within the scope of salvation by means of Christ's atonement as an act of divine grace. But that is a different matter.

As I have characterised mere exemplarism it is not sufficient for Smith to undergo the religious transformative experience she does for it to count as a transformative experience of the atonement. Something is still missing, some quality that would make the work of Christ into an atonement as far as Smith is concerned. This is true whether the transformation she undergoes leaves her religious but not a theist, or a theist but not Christian. The point is that the transformation does not make of Smith a believer in what is sometimes called the 'great things of the gospel'. It falls short of that, though it may be the catalyst for a profound and lasting change in Smith's moral and spiritual orientation. Hence, the mere exemplarist view of Christ's work does not amount to an account of atonement as I am understanding the term here namely, as the doctrine according to which Christ somehow reconciles fallen human beings to Godself by means of some saving act. It may be that she has only a partial grasp of Christ's work and fails to see that it is, in fact, an atonement. And, as I have

\footnotetext{
${ }^{12}$ Krattenmaker is an example of a non-theistic Jesus follower (see previous note). Hindu devotion to Christ as an avatar of Vishnu is an example of what we might term henotheistic Jesus devotion.

${ }^{13}$ I avoid the term 'church' here because there are some Christian faith communities that do not appear to be churches in the classical sense of the term, e.g. the Society of Friends (Quakers) or the Salvation Army.
} 
indicated, it may be that Christ's work is, in point of fact, an atonement for Smith, even though Smith has failed to perceive that. Be that as it may, it looks like mere exemplarism does not amount to a doctrine of atonement.

\section{Extended exemplarism}

Let us turn to extended exemplarism. As I indicated in the introduction to this article, extended exemplarism includes almost all the conceptual content of mere exemplarism. Like the mere exemplarist, the extended exemplarist thinks of Christ's work as a moral example of how we ought to live - a life of self-sacrifice culminating in the giving up of his own life in order to vindicate his message. But in addition to this, the extended exemplarist thinks that this very way of conceiving of the work of Christ provides her with a (thin) notion of reconciliation - that is, with an account of Christ's work as an atonement. To see this, let us consider a second example:

Jones is an ordinand minister in seminary and a close friend of Professor Smith. Jones has long held that Christ is a moral example whose life and work should form the moral foundation of a person's life. In fact, it was she who first suggested this to Smith, which set Smith off on her reading of the Gospels in her own quest for the good life. However, in her own theological formation, Jones has come to see that regarding Christ merely as a moral example is theologically insufficient. Only if Christ's example of love in his crucifixion is able to transform a person, changing them from someone alienated from God's love, to someone living a life of selfsacrifice and practical ministry, as a follower of Christ and member of the church, is his work sufficient. For, Jones thinks, the transformative work of Christ's loving example must bring us back into relationship with God. It must bring about not just a moral transformation but a spiritual reorientation and reconciliation with God.

It is more explicit in this example than in the case of Professor Smith that Jones has undergone what Laurie Paul calls an 'extended transformative experience', that is, a transformative experience that takes time, that may have different phases, and that may lead the person undergoing the experience to a very different way of life that she could not have anticipated prior to undergoing the experience in question. ${ }^{14}$ Through engagement with Christ's saving work, and especially his crucifixion, Jones comes to see that the love Christ displays is a divine love that should elicit a response of love from her. It should transform her, so that she comes to see something new about God's love in Christ reconciling the world to Godself, as well as a personal transformation through such an encounter. This total transformation (in the sense given by Laurie Paul) is at its core about bringing Jones back into alignment with God, from whom she has become estranged, by means of the love of Christ exemplified in his work on the cross. Such a religious experience may be construed as an instance of joint-attention with God, as Eleonore Stump and Adam Green (amongst others) have recently suggested. As Joshua Cockayne puts it in glossing Green's work on the topic:

According to Green's model, the individual who experiences God through joint-attention does not have to perform an inference to establish that she is experiencing God, but there is a kind of intersubjective relation that occurs

\footnotetext{
${ }^{14}$ Paul, Transformative Experience, p. 97.
} 
between God and her. The individual experiences something of God's emotions or intentions whether that be God's loving, or God's forgiving, or God's imparting mercy. $^{15}$

Perhaps Jones' transformative experience as a consequence of encountering and engaging the work of Christ as an atonement involves joint-attention in this way. Perhaps through engaging with the work of Christ Jones comes to see something of God's grace and love, comes to understand that Christ has shown her divine grace and comes to think that she is experiencing that love through the report of the atonement in the canonical Gospels that is applied directly and experientially to her through the secret working of the Holy Spirit. Perhaps it is this concatenation of different elements that together brings about her regeneration. ${ }^{16}$

Clearly, Jones' transformation includes a doctrine of atonement, which is something missing from the case of Professor Smith. ${ }^{17}$ Yet Jones' account is still recognisably a version of moral exemplarism: Christ's moral example, and his display of divine love, motivate Jones to undergo the religious transformative experience that leads through various stages to regeneration and salvation. ${ }^{18}$ It is important to note here that in the example of Jones there is no additional mechanism of atonement aside from Christ's moral example that factors into Jones' story. (Neither the notion of joint attention nor the internal work of the Spirit constitute mechanisms of atonement as such. They have to do with the application of the benefits of Christ's atonement to the believer.) It is a matter of Jones coming to understand Christ's moral example as a means by which she may be reconciled to Godself that yields the religious transformative experience that constitutes a thin understanding of atonement.

\section{Some objections to moral exemplarism}

As I have already suggested, moral exemplarism has often been the subject of criticism. In this section, we will focus on some of the standard objections to moral exemplarism to be found in the theological literature.

The first objection we shall designate the subjectivist-moralist worry. This relates to the discussion of subjective views of the atonement that was raised in connection with Adam Kotsko's essay. The worry is this: the exemplarist tradition is thoroughly subjective in its understanding of the work of Christ. The focus is upon inward, moral transformation not upon the objective work of Christ for us on the cross. Consequently, it

\footnotetext{
${ }^{15}$ Cockayne, 'The Imitation Game', p. 16. He is commenting on Adam Green, 'Reading the Mind of God (without Hebrew Lessons): Alston, Shared Attention, and Mystical Experience', Religious Studies 45/4 (2009), pp. 455-70.

${ }^{16}$ Exactly what to think about the nature and ontology of regeneration is an interesting question as well. For a recent discussion see Ben Page, 'If Anyone is in Christ - New Creation!' Religious Studies (2018), early view online, doi:10.1017/S003441251800063X

${ }^{17}$ Some might argue that the doctrine of atonement in the example of Jones is conceptually 'thin'. That may be true in the strictly philosophical sense (i.e. where 'thin' is not meant pejoratively, but just in terms of a conceptual minimum or threshold - what might be called a conceptual threshold for atonement). Nevertheless, the Jones example has the important Godward aspect of reconciliation that is not necessarily included in the previous example.

${ }^{18}$ For an interesting treatment of religious conversion as a transformative experience that draws on the work of L. A. Paul in dialogue with Søren Kierkegaard, see Andrew B. Torrance, 'Can a Person Prepare to Become a Christian? A Kierkegaardian Response’, Religious Studies 53 (2017), pp. 199-215.
} 
presents an inadequate understanding of Christ's saving work. Hastings Rashdall is sometimes thought to provide an example of this alleged inadequacy. He writes,

The Church's early creed 'There is none other name given among men by which we may be saved' will be translated so as to be something of this kind: 'There is none other ideal given among men by which we may be saved except the moral ideal which Christ taught by his words, and illustrated by his life and death of love; and there is none other help so great in the attainment of that ideal as the belief in God as he had been supremely revealed in him who so taught and lived and died.' So understood, the self-sacrificing life which was consummated by the death upon the Cross has, indeed, power to take away the sins of the whole world. ${ }^{19}$

But, it is not clear to me that the moral exemplarist must conclude that the importance of Christ's work is merely subjective and purely moralistic. One of the take-aways from Laurie Paul's work is surely that transformative experiences can have momentous change for the person who undergoes them, change that reshapes a person's life. That appears to be true of the mere exemplarist example of Professor Smith. It is even more the case for the extended exemplarist, Jones. It seems that the way this concern is often raised mischaracterises the moral exemplarist tradition. The idea is not to recommend a kind of moral formalism as reflected in the teaching of Christ - a sort of Kantianism in a clerical collar. Rather, I take it that the idea is about how Christ's example can be morally and spiritually transformative. The subjectivist-moralist worry is even less applicable to the extended exemplarist because it is clear that on this way of thinking Christ's work does much more than bring about subjective change or moral reorientation. It is truly transformative (in the sense used earlier in connection with discussion of Laurie Paul's work) and does encompass a notion of atonement.

A second and related objection is the problem of salvation by meritorious works. Alister McGrath puts it bluntly in his assessment of Rashdall's version of mere exemplarism: 'It amounts to nothing less than a doctrine of salvation by merit. ${ }^{, 20}$ Such concerns are often raised with respect to the exemplarist tradition. But it is not clear that this must be the case of either the mere moral exemplarist or the extended moral exemplarist. Take the mere exemplarist. The transformation undergone by Professor Smith is not a case of salvation by merit because it is not clearly an example of salvation at all. Her engagement with the work of Christ results in a transformative experience. But on neither the religious-but-not-a-theist interpretation of Smith's experience, nor the theist-but-not-Christian interpretation would it be true to say that Smith conceives of her engagement with the work of Christ in terms of salvation by merit or by works. This is just a misunderstanding of what is at issue.

This objection also misses the mark with respect to the case of Jones, the extended exemplarist. Her engagement with the work of Christ does not yield an idea that by performing certain actions she will place herself in the right state to merit salvation or to

\footnotetext{
${ }^{19}$ Hastings Rashdall, The Idea of the Atonement in Christian Theology, Being the Bampton Lectures for 1915 (London: Macmillan, 1920), p. 463. McGrath regards this excerpt from Rashdall as evidence for the view that 'man must find his own way to salvation by his good works executed in the imitation of the example of Christ' (McGrath, 'Moral Theory of the Atonement', p. 212). It is not quite as clear to me that this is the only way to read Rashdall's views here.

${ }^{20} \mathrm{McGrath}$, 'Moral Theory of the Atonement', p. 219. McGrath is scathing of Rashdall's version of exemplarism, but more sympathetic to what he takes to be the more sophisticated version of the view found in Immanuel Kant's Religion Within the Limits of Reason Alone.
} 
gain access to divine salvific grace. Rather, through the transformative process of engaging the work of Christ, she comes to see that his loving work reconciles her to Godself. She understands that by engaging with his work in a deep, spiritually reorienting manner, her alienation from God can be healed. There is no reason why this must be thought of as the work of Jones making herself right with God in some manner. A more charitable way to think of what is going on here is in terms of a work of divine grace through a kind of joint attention. God working through the example of Christ's loving action draws Jones to Godself.

The third concern is the problem of sin. Neither Smith nor Jones seem to have a particularly robust understanding of sin, let alone the doctrine of original sin. For many theologians, this is the most serious problem facing advocates of the exemplarist tradition. However, much of the force of this objection depends on one's broader theological commitments. Not all Christians hold to a doctrine of original sin or think that $\sin$ is a deep and debilitating problem for fallen human beings (e.g. the Orthodox, with their notion of the ancestral $\sin ^{21}$ ). Given that mere exemplarists do not regard Christ's work as salvific, and therefore do not think of it as an atonement, strictly speaking, the problem of sin does not arise in quite the same way. (One could object that the mere exemplarist has too sunny an estimation of human beings, but, though not unrelated, that is a rather different sort of worry.) Admittedly, as I have characterised the view here, the extended exemplarist doesn't think of sin as the obstacle to reconciliation with God. Rather, alienation is the problem at issue; a broken relationship that needs to be healed. That may be thought an inadequate account of human fallenness. But it is not necessarily inconsistent with all branches of Christianity (e.g. Orthodoxy again), and it is not clear to me that this presents a view of human nature that is objectionably optimistic in a theological sense. For instance, it is not obviously Pelagian or semi-Pelagian. ${ }^{22}$ And, of course, if the extended moral exemplarist characterises sin as alienation from God, she does have an account of sin after all. In that case the problem of sin objection straightforwardly fails to get off the ground. ${ }^{23}$

The fourth objection is the problem of the missing mechanism. This does not apply to mere exemplarism, since in that case there is no mechanism of atonement in view, just a significant trigger for a transformative experience. In the case of extended exemplarism there is what might be termed a conceptual-threshold mechanism of atonement. It is still not all that clear how Christ's work is an atonement on the extended exemplarist view. Somehow Christ's loving work generates an appropriate response by means of divine grace that illuminates and changes Jones, bringing her reconciliation with God and the kind of regeneration requisite to full participation in the life of the believing community. It might be desirable to have a clearer picture of the mechanism of atonement than this. But the extended exemplarist may resist that claim. Like Michael Gorman, she may be an atonement mechanism sceptic. That is, she may think that the New Testament authors don't give us a clear mechanism of atonement, and are not interested in doing so. Rather, their focus is on the practical consequences of Christ's saving work. Perhaps, the extended exemplarist might say, this should inform how we think about the

\footnotetext{
${ }^{21}$ See John S. Romanides, The Ancestral Sin (Ridgewood, NJ: Zephyr Publishing, 2002).

${ }^{22}$ Pelagianism is (very roughly) the heresy that human beings are capable of bringing about their own salvation through meritorious action. Semi-pelagianism is the view that human merit, coupled with divine grace, may bring about human salvation (namely, that human beings can really and truly contribute to their own salvation).

${ }^{23} \mathrm{I}$ am grateful to an anonymous reviewer for this point.
} 
nature of the atonement today. Perhaps we should be less concerned with clarifying the mechanism of atonement (which does not seem to have been a preoccupation of the New Testament authors) and more concerned about the practical (and measurable?) difference our atonement theology makes - a kind of pragmatic approach to atonement theology. ${ }^{24}$

But even if one is persuaded by the sort of atonement mechanism scepticism of biblical scholars like Gorman, there do seem to be important ways in which even the extended exemplarism of Jones is deficient from a New Testament point of view. I cannot give a complete account of this here. It will have to suffice to indicate three important biblical-theological motifs that seem to be lacking on the extended exemplarist way of thinking about the atonement. These are that Christ's work is substitutionary, representational and expiatory. I will briefly touch on each of these issues in turn.

Christ's atonement is substitutionary in nature. This seems to me indisputable on the basis of the New Testament texts and in the history of reflection upon them in atonement theology. That is, Christ acts vicariously on the part of those for whom his work is an atonement. In this way, substitution involves some notion of replacement of one thing by another, in this case of the fallen human being by Christ. He stands in the place of fallen human beings, so to speak (e.g. Rom 5:12-19; 2 Cor 5:21; Gal 3:10-13; 1 Pet 2:24, 3:18). There are different ways in which one thing can substitute for another. The sort of substitutionary act I have in mind here is one that is consistent with the notion of representation.

A representative is a part of a particular body or group. As biblical scholar Simon Gathercole points out,

Substitution entails the concept of replacement, $\mathrm{X}$ taking the place of $\mathrm{Y}$ and thereby ousting $\mathrm{Y}$ : the place that $\mathrm{Y}$ previously occupied is now filled by $\mathrm{X}$. In representation, $\mathrm{X}$ in one sense occupies the position of $\mathrm{Y}$, as in substitution. There are differences, however. In representation, $\mathrm{X}$ does not thereby oust $\mathrm{Y}$ but rather embodies Y. Indeed, it is usually a presupposition of representation that $\mathrm{X}$ belongs to group $\mathrm{Y}$, and so the representative is part of the body represented. ${ }^{25}$

Not all substitutes are also representatives in this sense. (Think of a body-double who may act as a substitute for a democratically elected political leader, though the bodydouble is not in fact the duly elected representative.) It seems to me that, in the case of the atonement, Christ is both a substitute and representative (see Rom 5:12-19 and 1 Cor 15). He acts on behalf of fallen human beings, and he represents those human beings as someone who is himself a human being. ${ }^{26}$

To this we may add the notion of expiation. That is, Christ's atonement blots out human sin; he makes amends so that human beings may be reconciled with God. (The language of 'sin offering' in Pauline theology, including the notion of Christ being 'made sin for us' is salient in this respect; see Rom 3:25; 1 Cor 5:21; Eph 1:7; 2:13; Col 1:20). ${ }^{27}$ If Christ's atonement is a sin offering provided in order to expiate

\footnotetext{
${ }^{24}$ Here I have in mind something like an analogue to Richard Swinburne's notion of pragmatic faith, where a person acts in a certain manner in the hope that belief will follow practice. See Richard Swinburne, Faith and Reason, 2nd edn (Oxford: Oxford University Press, 2005 [1981]), ch. 4.

${ }^{25}$ Simon Gathercole, Defending Substitution: An Essay on Atonement in Paul (Grand Rapids, MI: Baker Academic, 2015), p. 20.

${ }^{26}$ Ibid., Introduction.

${ }^{27}$ I think there is also a prima-facie case for thinking that God may be propitiated by Christ's atonement, though this is a much more controversial theological claim, which I won't defend here. The difference is that propitiation turns away wrath, whereas expiation removes sin-guilt.
} 
human sin (on analogy with the scapegoat of the Old Testament), then this may also turn away wrath even if it is not a propitiation, strictly speaking. Compare a situation in which someone breaks an expensive vase and then makes amends by purchasing a replacement as a substitute for the one that was broken. This act of expiation or making amends might also please the person whose vase was broken, thereby preventing unhappiness or anger even if the happiness this generates is merely a foreseen but unintended outcome (the intention being to make amends rather than to placate the person whose vase was smashed).

It is difficult to see how the exemplarist can address these three New Testament atonement motifs. Even if one is a mechanism sceptic, some account needs to be given regarding the biblical material that points in the direction of Christ's work being an atonement that is substitutionary, representational, and expiatory. The onus is on the exemplarist to provide some account of these matters.

\section{Conclusion}

Despite the resurgence of interest in the doctrine of atonement in recent biblical studies, systematic theology, and analytic theology, the exemplarist tradition has remained largely under-explored, with one or two notable exceptions. ${ }^{28}$ Even when it is introduced into the discussion, it is largely in order to dismiss it as an inadequate account of Christ's work. Sometimes it is mentioned alongside other 'theories' or models of atonement, as with Gustaf Aulén's influential threefold typology of objective (satisfaction), subjective (exemplarist) and dramatic (or Christus Victor) views of the atonement. ${ }^{29}$ None of these ways of thinking about the exemplarist tradition does it justice. I have argued that some versions of exemplarism (namely, mere exemplarism) are not in fact doctrines of atonement at all, although engagement with Christ's work understood in these terms may yield significant moral and transformational change in a person. Nevertheless, there is a second version of exemplarism, the extended account, that does amount to a doctrine of atonement. I have also argued that a number of standard objections to moral exemplarist views of Christ's work fall short of rebutting exemplarism. Nevertheless, moral exemplarism does seem to have deficiencies. Its doctrine of sin may be insufficient (depending on one's views on this matter). A not unrelated concern is the fact that the exemplarist tradition doesn't sufficiently engage three concepts in atonement theology rooted in scripture. These are the notions of substitution, representation and expiation. It is difficult to see how exemplarism alone, without theological augmentation, can adequately address these issues. For this reason, it seems to me to present an incomplete account of the work of Christ understood as a doctrine of atonement.

\footnotetext{
${ }^{28} \mathrm{John}$ Hick is the most notable recent proponent of some kind of moral exemplarism, but his account is derivative. It is not really in any sense an improvement upon, or development of, his predecessors such as Kant, Schleiermacher, or Rashdall. Nevertheless, his account is accessible. See Hick, The Metaphor of God Incarnate, 2nd edn (Louisville, KY: Westminster John Knox Press, 2005 [1993]).

${ }^{29}$ See Gustaf Aulén, Christus Victor: An Historical Study of the Three Main Types of the Idea of Atonement (London: SPCK, 1931).
}

Cite this article: Crisp OD (2020). Moral exemplarism and atonement. Scottish Journal of Theology 73, 137-149. https://doi.org/10.1017/S0036930620000265 